\title{
Effects of testosterone on testicular inhibin and fluid production in intact and hypophysectomized adult rats*
}

\author{
C. L. Au†, D. C. Irby, D. M. Robertson and D. M. de Kretser \\ Department of Anatomy, Monash University, Clayton, Victoria 3168, Australia
}

\begin{abstract}
Summary. Rats were given s.c. implants of high (HT) or low (LT) doses of testosterone and 10 days later hypophysectomy or sham-operation was performed. The rats were killed after 50 days. Unilateral efferent duct ligation was performed $16 \mathrm{~h}$ before death to measure seminiferous tubule fluid production and the increment in testicular inhibin values (inhibin production). Inhibin levels in testis cytosols were measured by a pituitary cell culture bioassay. The LT implants maintained serum testosterone at control values and decreased testicular weight whereas $\mathrm{HT}$ implants raised serum testosterone 3-fold and maintained testicular weight at $75-85 \%$ of pretreatment levels. In intact rats, LT implants caused no change in testicular inhibin content but decreased inhibin production; no significant changes occurred with HT implants. After hypophysectomy both values were significantly suppressed and could not be maintained by HT or LT implants. However, the HT implants partly restored inhibin production despite their inability to influence testicular inhibin content. In contrast, tubule fluid production depended mainly on intratesticular testosterone levels and occurred normally in intact or hypophysectomized rats with HT but not LT implants. These results indicate that inhibin and seminiferous tubule fluid production, both functions of the Sertoli cell, are under different hormonal control. The maintenance of inhibin production by the testis requires the support of pituitary hormones, presumably FSH, while seminiferous tubule fluid production requires testosterone, presumably through LH stimulation of Leydig cells. These findings are consistent with the hypothesis that inhibin is produced in response to trophic stimulation by FSH.
\end{abstract}

\section{Introduction}

Au, Robertson \& de Kretser (1985) have demonstrated that FSH, but not testosterone or hCG, is able partly to restore the testicular inhibin content of chronically hypophysectomized rats, implicating FSH in the control of testicular inhibin production. However, in these experiments the testis had been allowed to regress for 30 days and the hormonal replacement was of short duration. The possibility that testosterone could maintain testicular inhibin production if administered immediately after hypophysectomy was not excluded in those experiments. Other studies have implicated testosterone in the control of inhibin production in cultures of immature Sertoli cells (Verhoeven \& Franchimont, 1983), and androgen binding protein (ABP) secretion by Sertoli cells in vivo can be maintained by testosterone if given immediately after hypophysectomy.

This study set out to examine the effect of different levels of testosterone administered by subcutaneous implants on the inhibin content of the testis in intact and hypophysectomized adult rats. Furthermore the effect of this treatment on seminiferous tubule fluid production and testicular

\footnotetext{
* Reprint requests to Dr D. M. de Kretser.

† Present address: Department of Physiology, Chinese University of Hong Kong, Shatin, N.T., Hong Kong.
} 
inhibin production was explored by previously established techniques involving unilateral efferent duct ligation (Au et al., 1984).

\section{Materials and Methods}

Sprague-Dawley rats, aged 70 days, were obtained from the Monash University Central Animal House. Two sizes of testosterone implants, a low dose (LT, $25 \mathrm{~mm})$ and a high dose (HT, $200 \mathrm{~mm})$, were prepared from medical grade Silastic tubing (No. 602-305, $1.98 \mathrm{~mm}$ i.d. and $3.18 \mathrm{~mm}$ o.d.; Dow Corning, MI, U.S.A.) using the method of Berndtson, Desjardins \& Ewing (1974). The testosterone-containing tubing was implanted subcutaneously and 10 days later groups of rats were sham-operated or hypophysectomized via the parapharyngeal approach. Intact and hypophysectomized controls were anaesthetized at the time of testosterone capsule implantation but did not receive empty implants. The rats were killed by decapitation 50 days later, i.e. at 130 days of age. The experimental groups therefore consisted of: Group 1, controls killed at 70 days; Group 2, controls killed at 130 days; Group 3, intact rats with HT implants; Group 4, intact rats with LT implants; Group 5, hypophysectomized rats with HT implants; Group 6, hypophysectomized rats with LT implants; Group 7, hypophysectomized rats.

At $16 \mathrm{~h}$ before killing the rats, unilateral efferent duct ligation was performed by the method of Smith (1962). Testis extracts were prepared for the measurement of intratesticular testosterone and inhibin levels, the latter using an in-vitro bioassay as previously described (Au et al., 1983). Differences in inhibin content and weight between the ligated and non-ligated testes were taken as indices for the inhibin and seminiferous tubule fluid production by these animals (Au et al., 1984). Sera were also collected for the measurement of FSH, LH and testosterone by radioimmunoassays. Intratesticular levels of testosterone in the non-ligated testes were measured by assaying aliquants of testis cytosols. Seminal vesicles were weighed together with their content. The completeness of hypophysectomy was based on the absence of any pituitary fragments in the sella turcica at autopsy, and decreases in serum gonadotrophin concentrations, testicular and seminal vesicle weights. Otherwise, data from the animal were discarded.

In-vitro inhibin bioassay. A pituitary cell culture system (Scott, Burger \& Quigg, 1980) was validated for the measurement of inhibin activity in rat testes (Au et al., 1983). Testicular cytosols were prepared in Dulbecco's phosphate buffer and incubated with equal volumes of $1 \%$ Norit A charcoal at $4^{\circ} \mathrm{C}$ for $30 \mathrm{~min}$ to remove endogenous steroids before assay. The extracts were then serially diluted 2-4 times and assayed in triplicate at each dose level. The inhibin potency of each sample was determined in terms of an ovine testicular lymph reference preparation assigned a potency of $1 \mathrm{U} / \mathrm{mg}$ (Eddie, Baker, Higginson \& Hudson, 1979). The average assay index of precision $(\lambda)$ in 57 assays was $0 \cdot 102$ (range: $0 \cdot 070-0 \cdot 162$ ). The interassay coefficient of variation was assessed from the repeated analysis of two samples, a rat testicular extract pool and an ovine rete testis fluid preparation. These values were respectively $25 \cdot 4 \%$ (20 assays) and $15.0 \%$ (10 assays).

Radioimmunoassays. Serum FSH and LH concentrations were measured by double-antibody radioimmunoassays as previously described (Au et al., 1983) using reagents supplied by the NIADDK, NIH, MD, USA. Values were expressed in terms of the rat standards FSH-RP-1 and LH-I5. The sensitivity of the FSH assay was $100 \mathrm{ng} / \mathrm{ml}$ and that of the $\mathrm{LH}$ assay was $0.1 \mathrm{ng} / \mathrm{ml}$. Hormone concentrations in all samples were measured in the same assay and the within-assay coefficient of variation ranged from $4 \cdot 0$ to $9.7 \%$ for both assays.

Testosterone in sera and testicular cytosols was extracted with ether before measurement by a double-antibody radioimmunoassay. The 3-oxime-testosterone- ${ }^{125} \mathrm{I}$-histamine conjugate, prepared by the chloramine-T procedure (Bolton \& Hunter, 1973), was used as the tracer. The first antibody was raised in rabbits against testosterone-3-oxime-BSA conjugate and showed significant cross-

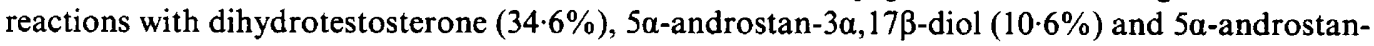


$3 \alpha, 17 \beta$-diol $(8.5 \%)$. The second antibody was raised in goats against rabbit immunoglobulin $\mathrm{G}$. Bound and free hormones were separated following a second antibody preparation step facilitated by polyethylene glycol (6\% polyethylene glycol 6000 in saline; Merck, Munich, FRG). The sensitivity of the testosterone assay was $50 \mathrm{pg} / \mathrm{ml}$. The intra-assay and inter-assay coefficients of variation were $6.7 \%$ and $12 \cdot 7 \%$ respectively.

Statistical analyses. Parallel-line bioassay statistics were used in calculating inhibin activities of the unknowns (Finney, 1964). Comparisons between values of different groups were made by analysis of variance and Student's $t$ test.

\section{Results}

\section{Testis weight}

The animals in Group 2 showed an increment in testis weight over the pre-treatment value (Group 1: Table 1). The testis weight in all treatment groups was significantly $(P<0.01)$ lower than in either of Groups 1 and 2.

Table 1. Changes in body and testicular weight of intact and hypophysectomized (hypox.) rats with or without subcutaneous Silastic implants containing a low (LT: $25 \mathrm{~mm}$ implant) or high (HT: $200 \mathrm{~mm}$ implant) dose of testosterone

\begin{tabular}{|c|c|c|c|c|c|c|c|}
\hline & $\begin{array}{l}\text { Group } 1 \\
\text { (70 days, } \\
\text { control) }\end{array}$ & $\begin{array}{c}\text { Group } 2 \\
\text { (130 days, } \\
\text { control) }\end{array}$ & $\begin{array}{c}\text { Group } 3 \\
\text { (HT, } \\
\text { intact) }\end{array}$ & $\begin{array}{c}\text { Group } 4 \\
\text { (LT, } \\
\text { intact) }\end{array}$ & $\begin{array}{c}\text { Group } 5 \\
\text { (HT }+ \\
\text { hypox.) }\end{array}$ & $\begin{array}{c}\text { Group } 6 \\
\text { (LT+ } \\
\text { hypox.) }\end{array}$ & $\begin{array}{l}\text { Group } 7 \\
\text { (hypox.) }\end{array}$ \\
\hline $\begin{array}{l}\text { No. of } \\
\text { animals }\end{array}$ & 7 & 7 & 7 & 8 & 8 & 8 & 9 \\
\hline Body wt (g) & $\begin{array}{c}306 \pm \\
8^{*}\end{array}$ & $\begin{array}{c}476 \pm \\
12\end{array}$ & $\begin{array}{c}385 \pm \\
23^{*}\end{array}$ & $\begin{array}{c}434 \pm \\
19^{*}\end{array}$ & $261 \pm$ & $\frac{233 \pm}{5^{*}}$ & $\begin{array}{c}254 \pm \\
5^{*}\end{array}$ \\
\hline $\begin{array}{l}\text { Testicular } \\
\text { wt (g) }\end{array}$ & $\begin{array}{l}1.40 \pm \\
0.06^{*}\end{array}$ & $\begin{array}{c}1.72 \pm \\
0.06\end{array}$ & $\begin{array}{l}1.21 \pm \\
0.03^{*}\end{array}$ & $\begin{array}{l}0.73 \pm \\
0.02^{*}\end{array}$ & $\begin{array}{l}1.04 \pm \\
0.07^{*}\end{array}$ & $\begin{array}{l}0.45 \pm \\
0.04^{*}\end{array}$ & $\begin{array}{c}0.28 \pm \\
0.01^{*}\end{array}$ \\
\hline $\begin{array}{l}\% \text { change in } \\
\text { testicular } \\
\text { wt compared } \\
\text { with Group I }\end{array}$ & - & +22 & $-13 \cdot 5$ & -48 & -26 & -68 & -80 \\
\hline
\end{tabular}

Values are mean \pm s.e.m.

$* P<0.01$ compared with Group 2 value.

\section{Serum FSH and LH concentrations}

Serum gonadotrophin concentrations in Groups 1 and 2 were not significantly different (Fig. 1). A low testosterone dose (Group 4) gave significant $(P<0.01)$ suppression of serum FSH and LH by $31 \%$ and $72 \%$ respectively; a high dose of testosterone (Group 3) suppressed FSH levels further (by $49 \%$ ) but did not further reduce LH. After hypophysectomy, levels of both gonadotrophins were at the detection limits of the radioimmunoassays, indicating that the surgery was complete.

\section{Serum and intra-testicular testosterone concentrations and seminal vesicle weight}

There was no significant difference in serum testosterone concentrations between the control groups (1 \& 2) or animals in Groups 4 and 6 (Fig. 2a). The high testosterone dose (Group 3 \& 5) 

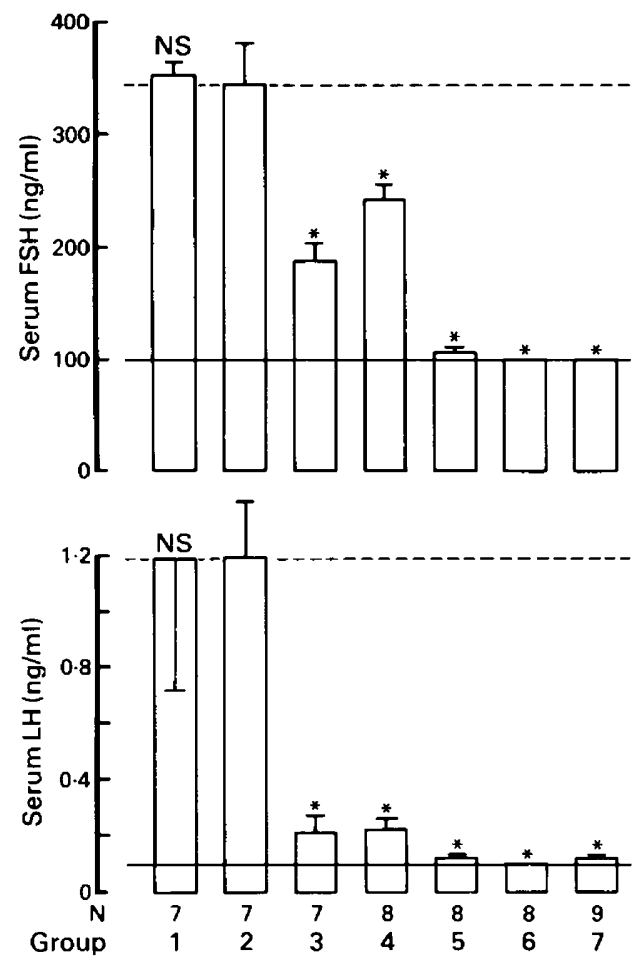

Fig. 1. Serum FSH and serum LH concentrations in intact (Groups 1-4) and hypophysectomized (Groups 5-7) rats with or without subcutaneous implants containing the low (Groups $4 \& 6$ ) or high (Groups $3 \& 5$ ) dose of testosterone. Group 1 represents the pretreatment values. Values are mean \pm s.e.m. for the number of animals indicated. The solid horizontal line in each histogram indicates the detection limit of the radioimmunoassay. The significance of differences $(P<0 \cdot 01)$ was assessed against the value for Group 2 (broken line). NS, not significant $(P>0.05)$.

produced a 3-fold increase in serum testosterone over the controls. Intact or hypophysectomized rats bearing the same lengths of implants did not have significantly different testosterone levels. Hypophysectomy alone (Group 7) resulted in a marked reduction in serum testosterone concentrations which reached $13 \%$ of control values.

The seminal vesicle weight of Group 2 animals was $34 \%$ higher than that of Group 1 (Fig. 2b). Testosterone implants produced further stimulation to reach about $146 \%$ in Group 4 (LT implants) and $230 \%$ with Group 3 (HT implants) of the weight found in Group 2. Hypophysectomy alone (Group 7) caused a marked regression of the gland to reach $10 \%$ of the weight in age-matched controls.

No significant difference in intratesticular testosterone levels was observed between Groups 1 and 2 or between animals, intact or hypophysectomized, bearing the same dose of testosterone implant (Fig. 3). However, even with the high dose, the levels were only maintained at $16 \%$ of the control. In animals in Groups 4 and 6 (low testosterone) the levels were significantly $(P<0.01)$ lower than in animals of Groups 3 and 5 and were only $4.4 \%$ of the controls (Groups $1 \& 2$ ). Hypophysectomy without testosterone implants (Group 7) led to extremely low levels of $<1 \%$ of the Group 2 values. 


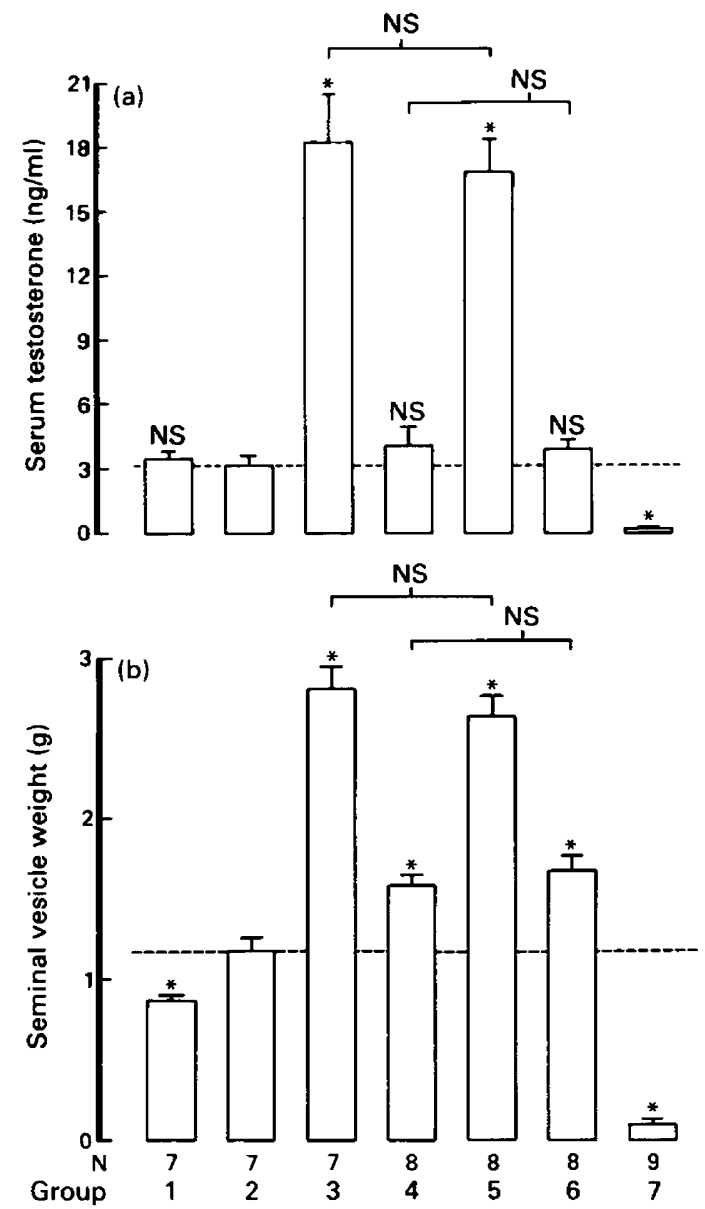

Fig. 2. Serum testosterone concentrations (a) and seminal vesicle weight (b) in intact (Groups 1-4) and hypophysectomized (Groups 5-7) rats with or without subcutaneous testosterone implants (low dose: Groups 4 \& 6; high dose: Groups 3 \& 5). Group 1 represents pretreatment values. Values are mean \pm s.e.m. for the number of rats indicated. ${ }^{*} P<0.01$ compared with Group 2 (broken line). NS, not significant $(P>0.05)$.

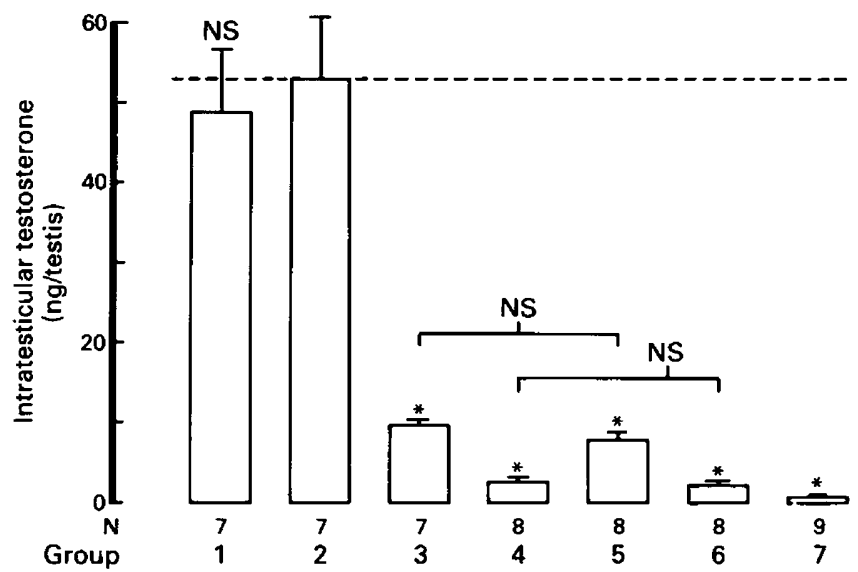

Fig. 3. Intratesticular testosterone concentrations in the testes of intact (Groups 1-4) and hypophysectomized (Groups 5-7) rats with or without subcutaneous testosterone implants (low dose: Groups 4 \& 6; high dose: Groups 3 \& 5). Group 1 represents pretreatment values. Values are mean \pm s.e.m. for the number of rats indicated. ${ }^{*} P<0.01$ compared with value for 


\section{Testicular inhibin content and production rate}

Intact rats, with or without testosterone implants (Groups 1-4), showed no significant differences in their testicular inhibin content (Fig. 4a). However, the inhibin production rate as determined by the unilateral efferent duct ligation technique was significantly $(P<0.01)$ lower in Group 4 rats and reached only $29 \%$ of the Group 2 value (Fig. $4 b$ ).

Hypophysectomy significantly $(P<0 \cdot 01)$ reduced both the testicular inhibin content and production rate below control levels (Groups 5-7). Inhibin production was partly restored in Group 5 (hypox. HT) without significantly improving the levels in the testis but was not altered in Group 6

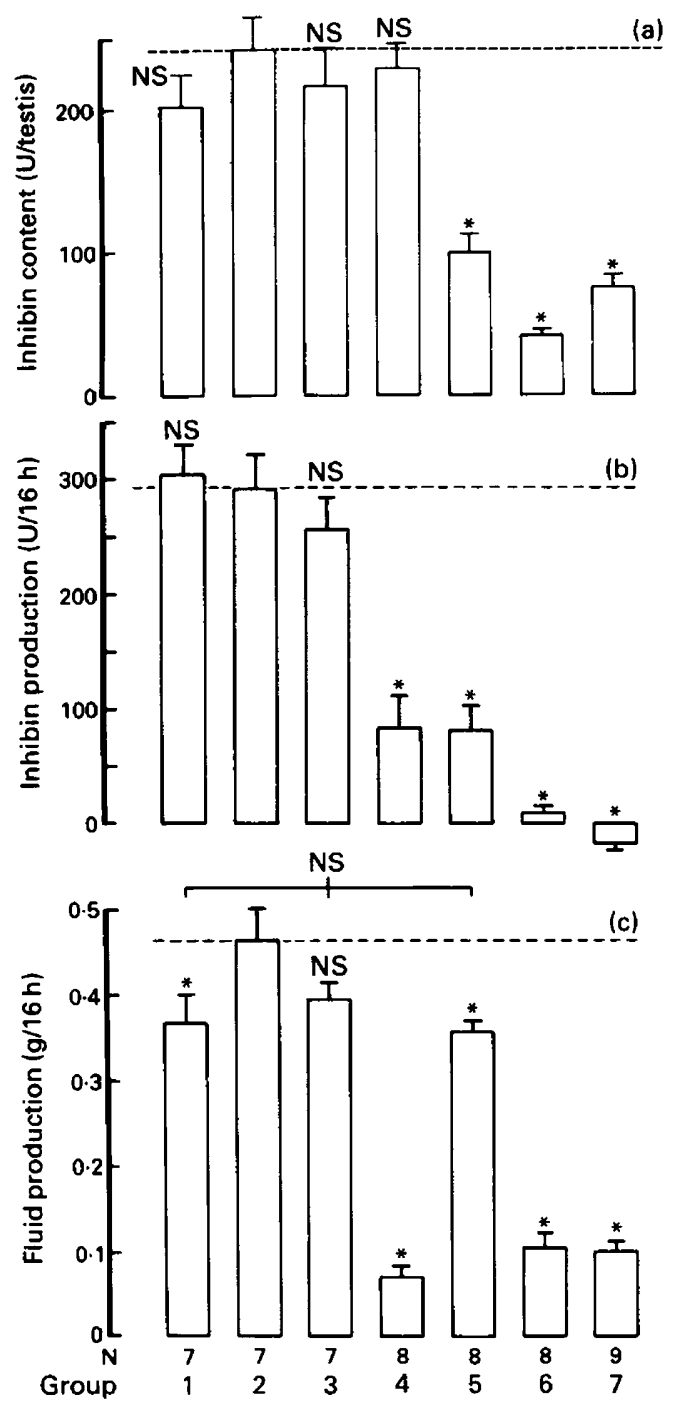

Fig. 4. Testicular inhibin content (a), testicular inhibin production rate (b) and seminiferous tubule fluid production rate (c) in intact (Groups 1-4) and hypophysectomized (Groups 5-7) rats with or without subcutaneous testosterone implants (low dose: Groups 4 \& 6; high dose: Groups $3 \& 5$ ). Group 1 represents pretreatment values. Values are mean \pm s.e.m. for the number of rats indicated. ${ }^{*} P<0.01$ compared with value for Group 2 (broken line). NS, not significant $(P>0.05)$. 
(hypox. LT). In Group 6, no significant difference was found between the inhibin content of the ligated and non-ligated testes, but in Group 7 animals, the inhibin level in the non-ligated testes was significantly higher $(P<0.05)$.

\section{Seminiferous tubule fluid production rate}

The rate of fluid production in Group 2 rats was significantly $(P<0.01)$ greater than in Group 1 (Fig. 4c). After hypophysectomy, fluid production decreased markedly to about $25 \%$ of the control (Fig. 4c). However, high doses of testosterone restored fluid production to values seen in Group 1 (70-day-old controls), and there were no significant differences $(P>0.05)$ between the values in Groups 3 and 5 (intact and hypox. HT-implanted rats). In contrast, a low testosterone dose significantly suppressed $(P<0.01)$ fluid secretion in intact and hypophysectomized animals (Groups 4 \& 6) to levels found after hypophysectomy alone (Group 7).

\section{Discussion}

This study demonstrates that the anterior pituitary gland is required in adult rats for the maintenance of the normal testicular inhibin content and production rate as measured by the increment after unilateral efferent duct ligation. Such findings are consistent with the concept that FSH is required to stimulate its target tissue to produce a specific feedback regulator, inhibin. Although a role for other pituitary hormones cannot be excluded, these results, when taken in conjunction with the ability of FSH partly to restore the testicular inhibin content after long-term hypophysectomy, indicate that FSH is the primary requirement (Au et al., 1985). However, in contrast, seminiferous tubule fluid secretion, another function of the Sertoli cell, can be maintained in hypophysectomized rats by high doses of testosterone which support spermatogenesis. Fluid production in Group 5 rats was maintained at levels achieved at the time of hypophysectomy and did not show the increment in fluid production between Days 70 and 130 .

Serum testosterone concentrations produced by the low and high testosterone implants are similar to values previously reported (Berndtson et al., 1974; Robaire, Ewing, Irby \& Desjardins, 1979; Decker, Loriaux \& Cutler, 1981). Although there are significant differences between the body weights of the intact and hypophysectomized testosterone-implanted rats (Groups 3 vs 5; Group 4 $v s 6$ ), serum testosterone concentrations were not significantly different, raising the question of a change in metabolic clearance rates of testosterone after hypophysectomy. The 'normal' physiological levels achieved by steady release from the low dose of testosterone implant, however, are not biologically equivalent to the episodic secretion from the testis. This view is evident from the present and other studies (Moger, 1976; Smith, Damassa \& Davidson, 1977; Schanbacher, 1980) in which significant stimulation of seminal vesicle weight and suppression of serum gonadotrophin concentrations are observed. The fact that serum LH is already maximally suppressed by the low testosterone implant, while even with the high dose serum FSH does not fall below $50 \%$ of control levels, again points to the need for postulating an independent control of pituitary FSH secretion in males besides the steroidal feedback by testosterone.

The present study shows that the maintenance of normal testicular inhibin content and production rate in adult rat testes requires anterior pituitary hormone(s). Our previous findings (Au et al., 1985) would suggest that the action of FSH is important, although the possibility of other pituitary hormones being involved cannot be excluded. These include $\mathrm{LH}$, prolactin and growth hormone which have been shown to be important in regulating testicular function (Woods \& Simpson, 1961; Lostroh, 1976; Bartke, 1980).

In intact rats bearing low testosterone implants, although the testicular inhibin content is maintained, the index of inhibin production as determined by the unilateral efferent duct ligation technique is significantly reduced. A similar discrepancy between testicular inhibin concentrations and its rate of secretion into the seminiferous tubules has previously been noted (Au et al., 1985). It is 
likely that the decrease in the inhibin production index under these conditions is due to a dysfunction of the inhibin secretory process rather than its synthesis. This view is supported by the finding that the secretion of seminiferous tubule fluid is impaired by the low intratesticular level of testosterone and may be the major reason why the index of inhibin production is decreased.

The production of inhibin and seminiferous tubule fluid both represent functions of the Sertoli cell. However, the present findings indicate that they exhibit significant differences in their hormonal control in adult rat testes. In contrast to the inhibin content and production rate, seminiferous tubule fluid secretion in hypophysectomized rats can be maintained by the high dose testosterone implant. Furthermore, since tubule fluid secretion in intact or hypophysectomized rats bearing low dose implants is reduced to levels found after hypophysectomy alone, it is very likely that the intratesticular concentration of testosterone is a major determinant in the maintenance of this process. Similar results have previously been reported when testosterone propionate or LH replacement given to adult hypophysectomized rats commencing at 4 days (Jégou, Le Gac, Irby \& de Kretser, 1983) or at 4 weeks (Free, Jaffe \& Morford, 1980) after surgery is able to restore fluid secretion. Nevertheless, Jégou, Le Gac \& de Kretser (1982) have shown that, in immature rats, tubule fluid production is stimulated by FSH but not by testosterone or LH. It is possible that the hormonal control of fluid secretion in immature and adult rat testes is different, or that the hormonal requirements for the initiation and maintenance of tubule fluid secretion are not the same. Furthermore, since the intratesticular testosterone levels in hypophysectomized rats treated with high-testosterone implants were only $16 \%$ of control, one cannot rule out the possibility that restoration of levels to $100 \%$ may raise the inhibin content and production to normal. Clearly such testosterone replacement would be of a magnitude far greater than that required to maintain spermatogenesis.

High- but not low-dose testosterone implants can maintain the testicular weight in hypophysectomized rats at $74 \%$ of the pre-treatment values. These data confirm the results of other workers showing that spermatogenesis in adult rats can be maintained qualitatively by high doses of testosterone alone (Walsh, Cuyler \& McCullagh, 1934; Clermont \& Harvey, 1965, 1967; Robaire \& Zirkin, 1981; Buhl, Cornette, Kirton \& Yuan, 1982). Furthermore, the changes in testicular weight in intact animals bearing high- or low-dose testosterone implants are consistent with the biphasic effect of testosterone on spermatogenesis (Ludwig, 1950; Berndtson et al., 1974). The 20-30\% reduction in testicular weight observed with the high dose could be related to the findings of Clermont \& Harvey (1967) who noted a $20-40 \%$ decrease in the number of type A spermatogonia in these animals and hence in the more mature germ cells. With the high- and low-dose testosterone implants, the testicular weights were significantly greater in the control than in the hypophysectomized animals (compare Groups 3 and 5, and 4 and 6). The difference in weight most probably represents the synergism between the testosterone dose and FSH since neither of these doses were able to suppress FSH to values seen in hypophysectomized rats.

It has been the general belief that high doses of testosterone support spermatogenesis mainly through maintaining a high intratesticular level of testosterone. The basis for this belief is the indirect evidence from clinical observations of steroid-secreting Leydig cell tumours in prepubertal males stimulating precocious development of the adjacent seminiferous epithelium (Root $e t$ al., 1972; Chemes, Pasqualini, Rivarola \& Bergada, 1982), and the ability of hCG but not testosterone injections (with FSH) to initiate spermatogenesis in hypogonadotrophic males (diZerega \& Sherins, 1981). However, studies of intact (Cunningham \& Huckins, 1979) and hypophysectomized (Buhl et al., 1982) rats have shown that spermatogenesis can be maintained by testosterone despite a great reduction in the intratesticular testosterone level. It is likely that the testosterone content in the whole testis may not truly reflect the level in the seminiferous tubule, which is believed to be of major importance for normal spermatogenesis. Such a view is supported by the data of Comhaire \& Vermeulen (1976) who showed that the ratio of seminiferous tubule fluid testosterone concentrations to those in interstitial fluid was higher when testosterone values in the interstitium fell. 
We thank Mrs S. Ellis, Miss M. S. Giacometti and Miss J. Lloyd for their technical assistance and Mrs Shirley Wainer for secretarial assistance. We acknowledge the NIADDK for the gonadotrophin radioimmunoassay kits. These studies were supported by grants from the National Health and Medical Research Council of Australia.

\section{References}

Au, C.L., Robertson, D.M. \& de Kretser, D.M. (1983) In vitro bioassay of inhibin in testes of normal and cryptorchid rats. Endocrinology 112, 239-244.

Au, C.L., Robertson, D.M. \& de Kretser, D.M. (1984) An in-vivo method for estimating inhibin production by adult rat testes. J. Reprod. Fert. 71, 259-265.

Au, C.L., Robertson, D.M. \& de Kretser, D.M. (1985) Effects of hypophysectomy and subsequent FSH and testosterone treatment on inhibin production by adult rat testes. J. Endocr. 105, 1-6.

Bartke, A. (1980) Role of prolactin in reproduction in male mammals. Fedn Proc. Fedn Am. Socs exp. Biol. $39,2577-2581$.

Berndtson, W.E., Desjardins, C. \& Ewing, L.L. (1974) Inhibition and maintenance of spermatogenesis in rats implanted with polydimethylsiloxane capsules containing various androgens. J. Endocr. 62, 125-135.

Bolton, A.E. \& Hunter, W.M. (1973) The labelling of proteins to high specific radioactivities by conjugation to a ${ }^{125} \mathrm{I}$-containing acylating agent. Biochem. $J$. 133, 529-539.

Buhl, A.E., Cornette, J.C., Kirton, K.T. \& Yuan, Y.D. (1982) Hypophysectomized male rats treated with polydimethylsiloxane capsules containing testosterone: effects on spermatogenesis, fertility and reproductive tract concentrations of androgens. Biol. Reprod. 27, 183-188.

Chemes, H.E., Pasqualini, T., Rivarola, M.A. \& Bergada, C. (1982) Is testosterone involved in the initiation of spermatogenesis in humans? A clinicopathological presentation and physiological considerations in four patients with Leydig cell tumours of the testis or secondary Leydig cell hyperplasia. Int. J. Androl. 5, 229-245.

Clermont, Y. \& Harvey, S.C. (1965) Duration of the cycle of the seminiferous epithelium of normal, hypophysectomized and hypophysectomized-hormone treated albino rats. Endocrinology 76, 80-89.

Clermont, Y. \& Harvey, S.C. (1967) Effects of hormones on spermatogenesis in the rat. Ciba Fndn Colloq. Endocr. 16, 173-196.

Comhaire, F.H. \& Vermeulen, A. (1976) Testosterone concentration in the fluids of seminiferous tubules, the interstitium and the rete testis of the rat. $J$. Endocr. 70, 229-235.

Cunningham, G.R. \& Huckins, C. (1979) Persistence of complete spermatogenesis in the presence of low intratesticular concentrations of testosterone. Endocrinology 105, 177-186.

Decker, M.H., Loriaux, D.L. \& Cutler, B.G., Jr (1981) A seminiferous tubular factor is not obligatory for regulation of plasma follicle-stimulating hormone in the rat. Endocrinology 108, 1035-1039.
diZerega, G.S. \& Sherins, R.J. (1981) Endocrine control of adult testicular function. In The Testis, pp. 127-140. Eds H. G. Burger \& D. M. de Kretser. Raven Press, New York.

Eddie, L.W., Baker, H.W.G., Higginson, R.E. \& Hudson, B. (1979) A bioassay for inhibin using pituitary cell cultures. J. Endocr. 81, 49-60.

Finney, D.J. (1964) Statistical Method in Biological Assay, 2nd edn. Charles Griffin, London.

Free, M.J., Jaffe, R.A. \& Morford, D.E. (1980) Sperm transport through the rete testis in anesthetized rats: role of the testicular capsule and effect of gonadotropins and prostaglandins. Biol. Reprod. 22 , 1073-1078.

Jégou, B., Le Gac, F. \& de Kretser, D.M. (1982) Seminiferous tubule fluid and interstitial fluid production. I. Effects of age and hormonal regulation in immature rats. Biol. Reprod. 27, 590-595.

Jégou, B., Le Gac, F., Irby, D.C. \& de Kretser, D.M. (1983) Studies on seminiferous tubule fluid production in the adult rat: effect of hypophysectomy and treatment with FSH, LH and testosterone. Int. J. Androl. 6, 249-260.

Lostroh, A.J. (1976) Hormonal control of spermatogenesis. In Regulatory Mechanisms of Male Reproductive Physiology, pp. 13-27. Eds C. H. Spilman, T. J. Lohl \& K. T. Kirton. Excerpta Medica, Amsterdam.

Ludwig, D.J. (1950) The effect of androgen on spermatogenesis. Endocrinology 46, 453-481.

Moger, W.H. (1976) Effects of testosterone implants on serum gonadotropin concentrations in the male rat. Biol. Reprod. 14, 665-669.

Robaire, B. \& Zirkin, B.R. (1981) Hypophysectomy and simultaneous testosterone replacement: effects on male rat reproductive tract and epididymal $\Delta^{4}-5 \alpha$ reductase and $3 \beta$-hydroxysteroid dehydrogenase. Endocrinology 109, 1225-1233.

Robaire, B., Ewing, L.L., Irby, D. \& Desjardins, C. (1979) Interactions of testosterone and estradiol-17 $\beta$ on the reproductive tract of the male rat. Biol. Reprod. 21, 455-463.

Root, A., Steinberger, E., Smith, K., Steinberger, A., Russ, D., Somers, L. \& Rosenfield, R. (1972) Isosexual pseudoprecocity in a 6-year-old boy with testicular interstitial cell adenoma. J. Pediat. 80, 264-268.

Schanbacher, B.D. (1980) Testosterone regulation of luteinizing hormone and follicle stimulating hormone secretion in young male lambs. J. Anim. Sci. 51, 679-684.

Scott, R.S., Burger, H.G. \& Quigg, H. (1980) A simple and rapid in vitro bioassay for inhibin. Endocrinology 107, 1536-1542. 
Smith, E.R., Damassa, D.A. \& Davidson, J.M. (1977) Feedback regulation and male puberty: testosteroneluteinizing hormone relationships in the developing rat. Endocrinology 101, 173-180.

Smith, G. (1962) The effects of ligation of the vasa efferentia and vasectomy on testicular function in the adult rat. $J$. Endocr. 23, 385-399.

Verhoeven, G. \& Franchimont, P. (1983) Regulation of inhibin secretion by Sertoli cell-enriched cultures. Acta endocr., Copenh. 102, 136-143.
Walsh, E.L., Cuyler, W.K. \& McCullagh, D.R. (1934) Physiologic maintenance of male sex glands: effect of androtin on hypophysectomized rats. Am. J. Physiol. 107, 508-512.

Woods, M.C. \& Simpson, M.E. (1961) Pituitary control of the testis of the hypophysectomized rat. Endocrinology 69, 91-125.

Received 24 April 1985 